記載種であると考えられている。このグループは環境に よる形態変異が著しく種同定に困難を極める。リンネ時 代のタイプ標本を用いた分子同定や世界各地の研究者に よる分子系統解析の結果をふまえ、日本産アオサ属藻類 の現状と、種同定のポイントについて概略する。

\section{第4回ワークショップ「船底塗料と海洋環境に関する最 新の話題」開催報告}

日本付着生物学会が共催した、日本マリンエンジニア リング学会（JIME）海洋環境研究委員会の第 4 回ワーク ショップ「船底塗料と海洋環境に関する最新の話題」が、 2015 年 9 月 16 日（水）および 17 日（木）に函館国際水 産・海洋総合研究センターで開催されました。このワー クショップは生物の付着機構、船底防污塗料、防污剤の 環境影響、生物越境移動問題をテーマに、2009年11月 に函館で第 1 回WS を、2011 年9月に千葉工大で第 2 回 WS を、2013 年9月に神戸大学で第3 回WS を開催してい ますので、今回は二度目の函館での開催となりました。

当日の函館は本当にさわやかな秋晴れで、参加者五十 数名を歓迎してくれました。

第1日目（9月16日）の研究講演会は、午前中、海上 技術安全研究所の小島隆志実行委員長の挨拶、伏谷伸宏 函館国際水産・海洋都市推進機構長の歓迎の言葉に続い て、日本付着生物学会加戸隆介会長（写真1）が招待講 演 1 ：「震災復興がもたらした人為的攪乱一外来種ナン オウフジッボの東北への侵入と分布拡大の懸念」を、ま た中国塗料(株)千葉知義氏が招待講演 $2 ： 「$ 船底防污塗 料および国際動向について」を話されました。午後は付 着生物、防污剤の環境残留・影響、新防污技術、防污技 術評価に関する 11 件の一般講演行われ、十分に質疑時 間が取られたので活発に議論が行われました。夜は、技 術交流会が函館国際ホテルで行われ、三十数名の参加が あり、こちらでも真剣かつ楽しい会話が続きました（写 真 2)。

第2日目（9月17日）は、函館国際・海洋総合研究セ ンターと函館どつくの施設見学会が行われました。

大変有意義な 2 日間で、関係者また参加者の皆様、あ りがとうございました。

次回第 5 回ワークショップは、2017年沖縄での開催が 話し合われております。

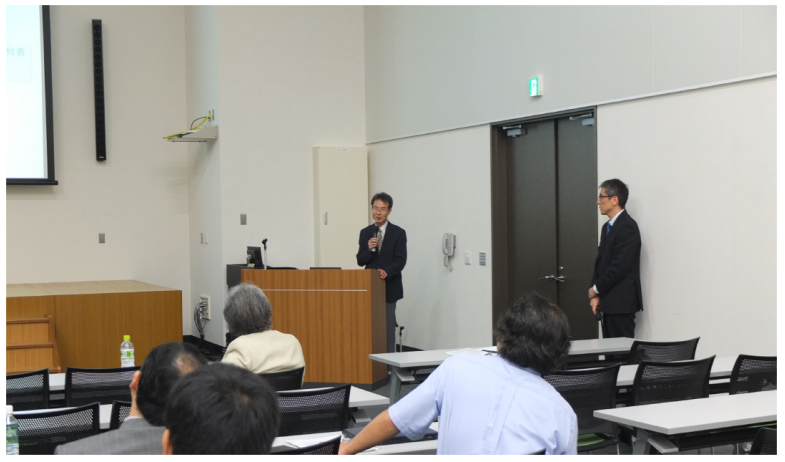

写真1。講演中の加戸会長

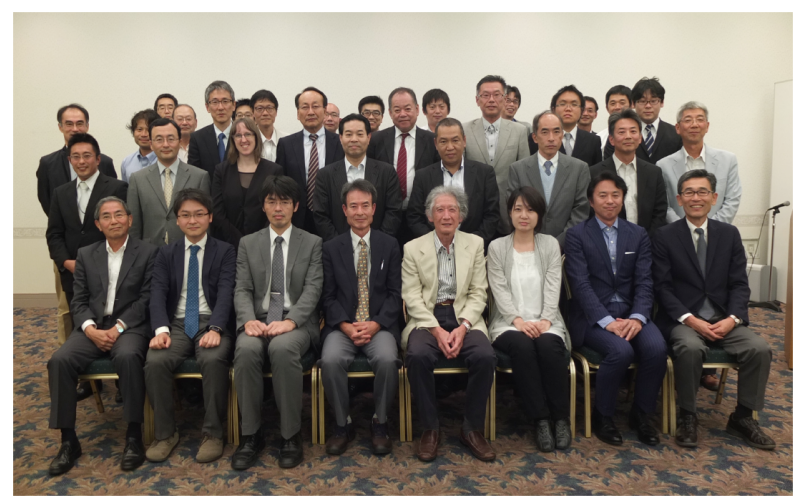

写真2. 技術交流会での記念写真 勝山一朗 記 